\title{
NOTICE TO RESIDENTS
}

Trenovch the good offices of one of the pharmaceutical houses, prizes will be given at the 1967 Canadian Anaesthetists' Society Meeting for presentations by residents in Canadian Hospitals.

First prize: $\$ 500.00$

Second prize: $\$ 200.00$

Third prize: $\$ 200.00$

Eight papers will be selected by the Programme Committee to be read before the meeting on Wednesday morning, June 28, 1967.

Papers may be of research, clinical, or review character, and they will be judged according to the material described, visual aids, and question period.

Submissions should reach the Canadian Anaesthetists' Society Secretary's Office, 178 St. George Street, Toronto 5, Ontario, not later than February 28, 1967.

The best eight papers will be selected for presentation at the 1967 meeting and be eligible for the awards. 